\title{
Implikasi Yuridis Pasal 9 Huruf (D) Dan (E) Undang-Undang Nomor 13 Tahun 2016 Terhadap Invensi Makhluk Hidup Yang Dikomersialisasikan Di Indonesia
}

\author{
Fajar Atho'illah Sudaryanto \\ Universitas Airlangga \\ fajarsudaryanto@gmail.com
}

\begin{abstract}
In International Intellectual Property of term wealth arrangement was evened out indentured kind sort and international negotiation, are next to be applied deep for national arrangement each its member state. In term international agreement implement in particular in TRIPs Agreement arise various problem kind for its member state, particularly in term limit to invention that can be patented. That thing is evoked because marks sense distinctive participant international behalf. Operated an by state flank need rule that really ties-up, meanwhile at effloresce state other side and retarded need technology averting for developmental its state. Research in this Journal collation constitutes a study normative on Intellectual wealth in particular in Patent regime in global trade traffic management. Besides difference problem in term limit to invention that can be patented, interesting thing under consideration this research is about impact which begat by distinctive invention limit, in its bearing with product importation into Indonesian. So needing severally source sentences, amongst those is included world trade agreement (World Trade Organization) WTO. Therefore, Act 13 (2016) about Patents as rule of basic hits regulation patents at Indonesian necessarily been determined ala clearing to hit National behalf as an aim and National aspiration.
\end{abstract}

\section{Keywords : Invention, Patent right. Commercialization}

\begin{abstract}
Abstrak
Dalam hal pengaturan Kekayaan Intelektual Internasional telah diselenggarakan berbagai macam perjanjian serta perundingan internasional, yang kemudian diterapkan dalam pengaturan nasional setiap negara anggotanya. Dalam hal penerapan perjanjian internasional khususnya dalam TRIPs Agreement timbul berbagai macam masalah bagi negara anggotanya terutama dalam hal pembatasan terhadap invensi yang dapat dipatenkan. Hal tersebut timbul karena adanya perbedaan kepentingan antar negara peserta. Di satu sisi, negara membutuhkan ketentuan yang sangat mengikat, sedangkan disisi lain, negara berkembang dan terbelakang membutuhkan alih teknologi untuk pengembangan negaranya. Penelitian ini merupakan suatu studi normative atas Kekayaan Intelektual khususnya dalam rezim Paten dalam penyelenggaraan lalu lintas perdagangan global. Selain masalah perbedaan dalam hal pembatasan terhadap invensi yang dapat dipatenkan, hal yang menarik dalam penelitian ini adalah mengenai dampak yang diakibatkan oleh perbedaan pembatasan invensi, dalam kaitannya dengan importasi produk ke dalam Indonesia, sehingga membutuhkan beberapa sumber hukum, diantaranya adalah perjanjian-perjanjian perdagangan dunia termasuk
\end{abstract}


(World Trade Organization) WTO. Oleh karena itu, Undang Undang Nomor 13 Tahun 2016 tentang Paten sebagai ketentuan dasar mengenai regulasi paten di Indonesia seharusnya ditentukan secara jelas mengenai kepentingan Nasional sebagai suatu tujuan dan cita-cita Nasional.

\section{Kata kunci: Invensi, Hak Paten. Komersialisasi}

\section{Pendahuluan}

Indonesia merupakan salah satu negara yang turut serta menandatangani persetujuan pembentukan organisasi perdagangan dunia (WTO) dan termasuk di dalamnya perjanjian mengenai aspek-aspek perdagangan yang terkait dengan Kekayaan Intelektual (selanjutnya disingkat KI) atau dalam (Agreement on Trade Related Aspects of Inteletual Property Rights). Perjanjian internasional tersebut diratifikasi oleh Indonesia dengan Undang Undang Nomor 7 Tahun 1994 tentang pengesahan Agreement Establishing The Worl TradeOrganitation (Irawan, 2011 : 1). Paten adalah bagian dari hak kekayaan intelektual, yang dalam kerangka ini termasuk dalam kategori hak kekayaan intelektual perindustrian (Industrial Property Right). Paten merupakan suatu hak khusus berdasarkan undang-undang diberikan kepada si penemu (uitvinder) atau menurut hukum pihak yang memperolehnya, atas permintaannya yang diajukan kepada pihak penguasa, bagi temuan baru di bidang teknologi, perbaikan atas temuan yang sudah ada, cara kerja (proses) baru, atau menemukan suatu perbaikan baru dalam cara kerja, untuk selama jangka waktu tertenu yang dapat diterapkan dalam bidang industry ( Irawan, 2011 : 223). Syarat suatu invensi atau penemuan yang dapat dipatenkan ada beberapa hal yang harus dimiliki yaitu memiliki syarat substantif tertentu. Penentuan bahwa suatu penemuan yang dimintakan Paten dapat diberi atau tidak dapat diberi Paten dilakukan antara lain dengan mempertim-bangkan: (1) kebaruan penemu (novelty); (2) dapat atau tidaknya penemuan diterapkan atau digu-nakan dalam perindustrian (industrial applicability); (3) langkah inventif yang terkandung dalam penemuan (inventive step); 
penemuan yang bersangkutan tidak termasuk dalam kelompok penemuan yang tidak dapat diberikan Paten; (5) penemu atau orang yang menerima lebih lanjut hak penemu berhak atas Paten bagi penemuan tersebut; dan (6) pene-muan tersebut tidak bertentangan dengan peraturan perundang-undangan, ketertiban umum serta kesusilaan. Jadi pada hakikatnya, sebuah penemuan dapat dikatakan Patentable bila memenuhi ketiga syarat substantif tersebut, yaitu novelty, dapat diterapkan dalam industri, dan mengandung langkah inventif (Purwaningsih, (2012:3).

Di Indonesia sendiri sebe-narnya terdapat potensi-potensi yang sangat banyak baik dari segi Sumber Daya Manusia (SDM) maupun dari segi Sumber Daya Alam (SDA) yang dimilikinya. Berkaitan dengan itu, seharusnya masyarakat Indonesia banyak memiliki hak paten. Sebenarnya Indonesia juga memiliki banyak sekali Sumber Daya Alam yang dapat dikelola dan dapat dipatenkan dalam bidang bioteknologi. Misalnya paten mengenai proses pembuatan antibiotika yang terbuat dari molusca. Invensi mengenai antibiotika yang berasal dari hewan molusca dan teknik untuk memperolehnya menjadi solusi untuk masyarakat. Dalam invensi tersebut diuraikan proses pembuatan antibiotika dari hewan molusca. Hasil uji dengan kertas cakram, protein dari lendir molusca mempunyai aktivitas antibiotika terhadap Bacillus subtilis, Staphylococcus aureus, Pseudomonas aeruginosa, dan Eschericia coli. Dalam hal uji inhibisi metabolit juga menunjukkan penghambatan pertumbuhan bakteri. Invensi mengenai pembuatan antibiotika dari moluska mendapatkan perlindungan paten dengan Nomor Paten : P00200100076 (ID P 0010056). (Direktorat Jendral Perguruan Tinggi (DIKTI)

(http://artikel.dikti.go.id/index.php/in vensi/article/view/ Diakses 2 November 2015).

Dalam perumusan UndangUndang HKI, Indonesia banyak meratifikasi dari perjanjianperjanjian Internasional. Dalam perumusan Undang-undang Paten misalnya, Pemerintah Republik 
Indonesia meratifikasi ketentuanketentuan dari Agreement On Trade-Related Aspects of Intellectual Property Rights (TRIPs). Dalam TRIPs banyak timbul ketidaksesuaian antara peraturan yang terkandung dengan norma-norma yang telah lahir dan hidup dalam masyarakat Indonesia. Dalam hal bioteknologi misalnya beberapa negara di dunia dapat mematenkan hasil invensinya yang berupa hewan dan tumbuhan serta proses untuk memelihara dan membudidayakannya karena mereka menerapkan TRIPs yang tercantum dalam Pasal 27 ayat (3)

Members may also exclude from patentability

a) Diagnostic, therapeutic and surgical methods for the treatment of humans or animals;

b) Plants and animals other than micro-organisms, and essen-tially biological process for the production of plants or animals other than non-biological and microbiological processes. However, Members shall provide for the protection of plant varieties either by patents or by an effective sui generis system or by any combination thereof. The provisions of this subparagraph shall be reviewd four years after the date of entry into force of the WTO Agreement. Agreement on Trade Related Aspects of Intellectual Property rights (TRIPs) SECTION.

Sedangkan dalam Pasal 9 (d) dan (e) Undang-undang Nomor 13 Tahun 2016 tentang Paten ditentukan bahwa :

Paten tidak diberikan untuk Invensi tentang

a) Semua makhluk hidup, kecuali jasad renik;

b) Proses biologis yang esensial untuk memproduksi tanaman atau hewan, kecuali proses non-biologis atau proses mikrobiologis.

Ketentuan diatas berbeda dimana dalam TRIPs membolehkan mengenai pemberian hak paten terhadap makhluk hidup dan prosesnya. Sedangkan Undangundang Nomor 13 Tahun 2016 tentang Paten tidak memberikan hak terhadap invensi berupa makhluk hidup dan prosesnya (kecuali yang diperkecualikan). Perbedaan ini menimbulkan masalah dimana suatu invensi di negara yang menerapkan 
TRIPs yang memper-bolehkan atau memberikan hak eksklusif terhadap suatu invensi tentang perwujudan invensi berupa makhluk hidup yang kemudian mengkomersialisasikannya di Indo-nesia yang menerapkan Undang-undang Nomor 13 Tahun 2016 tentang Paten yang tidak memperbolehkan atau tidak memberikan hak Paten untuk invensi yang berupa makhluk hidup dan proses yang menyertainya.

\section{Metode Penelitian}

Jenis penelitian yang digunakan adalah penelitian hukum normatif, suatu penelitian yang merupakan proses untuk menemukan aturan hukum, prinsip-prinsip hukum, maupun doktrin-doktrin hukum guna menjawab isu hukum yang menjadi permasalahan. Hal ini sesuai dengan prespektif ilmu hukum (Marzuki, 2010 : 35). Penelitian ini dipilih karena sesuai untuk menjawab isu hukum yang ada dengan menggunakan aturan hukum, prinsipprinsip hukum, serta perjanjian internasional yang berkaitan dengan Hukum Hak Kekayaan Intelektual khususnya pada rezim Paten.
Metode pendekatan yang digunakan adalah pendekatan perundang-undangan (statute approach) yang berarti dilakukan dengan menelaah semua undangundang dan regulasi yang bersangkut paut dengan isu hukum yang ditangani. Pendekatan ini digunakan karena dalam pendekatan ini menggunakan pendekatan undangundang dengan cara membuka kesempatan untuk mempelajari adakah konsistensi dan kesesuaian antara suatu undang-undang dengan undang-undang lainnya atau antara undang-undang dan undang-undang dasar atau antara regulasi dengan undang-undang. Dalam penelitian ini akan dilakukan penelaahan terhadap Undang-Undang Paten dengan perundang-undangan lainnya guna menjawab isu hukum.

\section{Pembahasan}

\section{Batasan-Batasan Invensi Yang Dapat Diajukan Berdasarkan Undang-Undang Paten Negara Republik Indonesia.}

$$
\begin{aligned}
& \text { Semakin majunya teknologi } \\
& \text { tentu saja sebanding dengan } \\
& \text { kebutuhan manusia yang semakin } \\
& \text { meningkat, bukan saja guna }
\end{aligned}
$$


pemenuhan kebutuhan akan barang dan/atau jasa, namun juga kepada pemenuhan kebutuhan global dan juga kesejahteraan secara luas, yang tidak hanya didapati di negara maju namun juga kepada dunia ketiga dan negara berkembang. Teknologi dapat diartikan sebagai suatu produk berupa benda-benda yang berguna bagi manusia, seperti mesin misalnya, tetapi dalam masa kini dapat juga mencakup hal yang lebih luas, termasuk sistem, metode organisasi, dan teknik. Istilah ini dapat diterapkan secara umum atau lebih spesifik: contoh-contoh mencakup teknologi konstruksi, teknologi medis, dan/atau (state-of-the-art technology). (Yonas, 2012)

http://www.perintiswebblog.blogspot.co. id/2012/08/hakiat-teknologi-

danteknologi.html, )

Perkembangan teknologi terbaru, termasuk mesin cetak, telepon, dan Internet, mengatasi hambatan fisik untuk komunikasi dan memungkinkan manusia untuk berinteraksi dengan bebas pada skala global atau luas. Namun, tidak semua teknologi ini telah digunakan untuk tujuan damai. Tetapi banyak proses-proses teknologi juga menghasilkan produk yang tidak diinginkan atau mengakibatkan sesuatu hal, seperti polusi, mengeksploitasi sumber daya alam, dengan merusak bumi dan lingkungannya. Implementasi teknologi mempengaruhi nilai-nilai masyarakat dan teknologi baru sering menimbulkan pertanyaan pertanyaan etika baru.

The Merriam-Webster menawarkan definisi dari istilah: "aplikasi praktis dari pengetahuan khususnya di daerah tertentu" dan "kemampuan yang diberikan oleh aplikasi praktis dari pengetahuan". Ursula Franklin, di 1989 dalam kuliah "Real World of Tekhnology ", memberi definisi lain dari konsep; itu adalah suatu praktik atau cara melakukan hal-hal yang berhubungan dengan ilmu pengetahuan". Istilah ini sering digunakan untuk menyiratkan bidang tertentu teknologi, atau untuk mengacu pada teknologi tinggi atau hanya konsumen elektronik, daripada teknologi secara keseluruhan. Bernard Stiegler, di Teknik dan Time, mendefinisikan teknologi 
dalam 2(dua) cara: sebagai "pengejaran kehidupan dengan cara selain hidup" (berupa alat yang berupa makhluk hidup dan/atau benda mati), dan sebagai "yang diselenggarakan materi anorganik.(yang berupa suatu rekasi dari benda mati )"

Dalam ketentuan TRIPs tidak ada definisi mengenai teknologi, namun jika diambil dari rancangan Conduct of Transfer of Technology ( Rancangan CC TT) dari United Nations Conference on Trade and Development (UNCTAD) istilah teknologi dapat diartikan sebagai:

"systematic knowledge for the manufacture of a product, for the application of a process or for the rendering of a service and does not extend to the transactions involving the mere sale or lease of goods."

Sedangkan dalam Pasal 1 butir 2 Undang-Undang Nomor 18 Tahun 2002 tentang Penelitian, Pengembangan, dan Penerapan Ilmu Pengetahuan dan Teknologi istilah teknologi diartikan sebagai cara atau metode serta proses atau produk yang dihasilkan dari penerapan dan pemanfaatan berbagai disiplin ilmu pengetahuan yang menghasilkan nilai bagi pemenuhan kebutuhan, kelangsungan, dan peningkatan mutu kehidupan manusia. Dari berbagai definisi tersebut Purba menyimpulkan bahwa teknologi memiliki unsur pengetahuan, sistematik, digunakan untuk berproduksi berupa aplikasi proses dan/atau pemberian jasa, serta berguna bagi kesejahteraan hidup atau kegunaan praktis lain (Purba, 2011 : 84). Jadi teknologi merupakan perangkat hal-hal yang paling esensial yang diperlukan bagi kehidupan setiap manusia.

Dalam hal status dari teknologi terbagi atas 2 (dua) bagian besar. Yang pertama teknologi yang dapat dilindungi dengan paten, sedangkan yang kedua tidak dapat dipatenkan yang termasuk keahlian (skill) dan juga keterampilan (technical know how). Technical know how diartikan sebagai

"knowledge and experience of a technical, commercial, administration, financial or other nature, which is practically applicable to the operation of an enterprise of an enterprise or the practice of a profession." 
Teknologi tidak hanya suatu sarana untuk menghasilkan suatu keuntungan ekonomi bagi penemunya saja, namun dalam hal ini juga teknologi dianggap sebagai pengisi pemenuhan kebutuhan masyarakat secara global serta teknologi dianggap sangat penting bagi pembangunan dan peradaban sosial ekonomi negara-negara tertinggal dan berkembang. Untuk hal itu alih teknologi dianggap sangat diperlukan untuk menunjang pemerataan konsep riset dan teknologi di dunia.

Mengenai Bioteknologi, secara harfiah setaip orang akan menguraikan definisi bioteknologi sebagai suatu paduan kata bio yang berarti makhluk hidup atau yang mempelajari dan teknologi yang berarti alat yang memudahkan kehidupan manusia dan yang mempelajarinya. Jelas bahwa bioteknologi adalah suatu terapan ilmu dari biologi yang dikombinasikan dengan paham ilmu yang mempelajari teknologi yang akan menunjang kemajuan industri pada setiap negara. Kondisi ini akan mendorong setiap negara untuk memiliki suatu keunggulan dalam bidang teknologi dan terapannya.

Seperti yang disebutkan bahwa bioteknologi merupakan suatu ilmu terapan dari ilmu biologi, maka hal tersebut dianggap terlalu luas, sehingga dibutuhkan batasan yang lebih sempit. Perhimpunan Kimia Murni dan Terapan (International Unions of Pure and Aplied Chemistry = IUPAC) mengemukakan rumusan bahwa bioteknologi adalah penerapan biokiamia, biologi, mikrobiologi, dan rekayasa kimia dalam proses industri pembuatan produk. Sedangkan Organization for Economic Cooperation and Development (OECD) mendefinisikan bioteknologi sebagai suatu penerapan asas ilmiah dan rekayasa pengolahan bahan olah agen biologi untuk menyediakan barang dan jasa.

Dalam berbagai perjanjian internasional yang menjadi dasar terbentuknya suatu sistem hukum nasional mengatur tentang dasardasar dan tata cara mengenai regulasi hukum. Dalam regulasi perjanjian internasional yang menaungi sistem KI misalnya setiap perjanjian 
internasional seperti The Agreement on Trade Related Aspects of Intellectual Property (TRIPs), The Paris Convention for the Protection of Industrial Property, Paten Cooperation Treaty (PCT), dan The Budapest Treaty on the Recognition the Deposit of Microorganisms for the Purposes of Patent Procedures (perjanjian-perjanjian internasional khusus dalam rezim paten) menentukan ketentuan dasar dalam mengatur regulasi tentang hak paten, namun dari semua perjanjian tersebut memberikan kewenangan kepada setiap anggotanya untuk menentukan sendiri peraturan perundang-undangannya guna menaungi kesejahteraan dan daya guna masyarakat dari negara tersebut.

Apabila ditelusuri, sebenarnya tujuannya adalah salah satu upaya negosiasi bagi setiap negara untuk menanamkan modalnya di dalam suatu negara yang dituju, kemudian negara tersebut akan menjadi pasar tersendiri untuk menjual invensi dari suatu negara yang telah memiliki hak paten. Selain tujuan tersebut sebenarnya ada tujuan sosial dari perumusan perjanjian-perjanjian internasional tersebut yakni untuk menjaga kelestarian hidup serta mensejahterakan masyarakat di dunia baik dari negara maju, negara berkembang, bahkan negara tertinggal. Ketentuan yang dibuat diatur untuk menjaga stabilitas perdagangan dunia. Namun dalam praktiknya, menjadi suatu alat yang dimanfaatkan oleh negara-negara maju untuk menjual seluruh produknya ke negara-negara yang membutuhkan terutama negaranegara tertinggal dan berkembang yang membutuhkan alih teknologi untuk membangun negaranya.

Seperti diketahui pada ujung abad ke-20 tercapai kesepakatan global negara-negara untuk memasukkan konsep hak kekayaan intelektual yang tertuang dalam The Agreement on Trade Related Aspects of Intellectual Property (TRIPs) sebagai bagian dari Agreement Establishing the World Trade Organization (WTO Agreement), sebagai perjanjian internasional mengenai perdagangan dunia yang dinaungi oleh Perserikatan Bangsa Bangsa (PBB). Persoalan inti di 
bidang perdagangan internasional adalah bagaimana mengupayakan agar lalu lintas perdagangan tetap lancar. TRIPs memiliki status hukum sebagai lampiran dari WTO yang mana hal tersebut tidak dapat dilepaskan karena telah menjadi suatu kesatuan serta tidak diperbolehkan untuk adanya reservasi terhadap WTO Agreement TRIPs (Purba, $2006: 7$ ).

Strategi memasukkan KI sekaligus dalam penegakan hukum sebagai unsur perdagangan internasional dianggap sangat efektif, dibandingkan perjanjian - perjanjian internasional lainnya. TRIPs dibuat satu paket dengan WTO, maka negara-negara menjadi terikat dengan kepentingan mereka di bidang perdagangan internasional pada umumnya. Yang menjadi isu dalam perjanjian TRIPs adalah invensi yang dapat dipatenkan menurut TRIPs yang ketentuannya terdapat dalam Article 27. Mengenai definisi dan penerapan Article 27 point (1) dan (2) dianggap hal tersebut telah sesuai dengan yang diinginkan dan dibutuhkan oleh setiap negara di dunia. Namun pada
Article 27 point (3) terdapat ketidaksesuaian dengan keinginan dan kebutuhan negara miskin dan berkembang.

Negara-negara maju umumnya menyatakan tidak ada biopiracy (pencurian sumber pengetahuan makhluk hidup dengan cara mematenkannya) yang dituduhkan oleh negara-negara berkembang. Berdasarkan Article 27 point (3).b TRIPs menurut kalangan negaranegara maju, jasad renik dapat dipatenkan paling tidak menurut rezim KI di Amerika Serikat dan Eropa yang mendasarkan pada inovasi individual yang dihasilkan para peneliti sekalipun berasal dari pengetahuan tradisional. (Purba, 2006 : 144). Persolan yang ditimbulkan adalah darimana asli material atau bahan itu, yang sejauh ini memang tidak merupakan masalah yang ditimbulkan dari TRIPs. beberapa unsur pokok dari Article 27 point (3) menyangkut tentang invensi yang tidak diperbolehkan dan pengecualian jasad renik dan proses non-biologis serta mikrobiologis. 
Dalam peraturan perundang- dengan peraturan perundangundangan khususnya pada bidang paten di Indonesia telah menerapkan standar minimal yang telah dtentukan oleh TRIPs. Seperti itu terlihat dalam pengecualian invensi yang diterapkan oleh Indonesia yakni dalam Pasal 9 Undang Undang Paten yang menentukan bahwa:

Invensi yang tidak dapat diberi Paten meliputi:

a) proses atau produk yang pengumuman, penggunaan, atau pelaksanaannya bertentangan dengan peraturan perundangundangan, agama, ketertiban umum, atau kesusilaan;

b) metode pemeriksaan, perawatan, pengobatan dan/ atau pembedahan yang diterapkan terhadap manusia dan/atau hewan;

c) teori dan metode di bidang ilmu pengetahuan dan matematika;

d) makhluk hidup, kecuali jasad renik; atau

e) proses biologis yang esensial untuk memproduksi tanaman atau hewan, kecuali proses nonbiologis atau proses mikrobiologis.

Menurut ketentuan tersebut bahwa permohonan invensi yang akan diajukan tidak boleh bertentangan dengan ketentuan tersebut. Artinya, pertama; invensi tersebut tidak boleh bertentangan undangan yang berlaku, moralitas agama, ketertiban umum, atau kesusilaan. Hal ini - bahwa Indonesia tetap menjunjung tinggi kepentingan nasional dan hak-hak komunal dari pada hak individual dalam kepentingan komersial. Yang kedua; metode pemeriksaan, perawatan, pengobatan dan/atau pembedahan tidak dapat dimohonkan patennya. Namun dalam hal alat, bahan, obat, maupun produk mengenai hal tersebut tetap dapat diajukan permohonan patennya. Yang ketiga; teori dan metode di bidang ilmu pengetahuan dan matematika tidak dapat dipatenkan karena hal tersebut bukan suatu invensi yang memenuhi persyaratan kebaruan dan inventive step. Sedangkan yang terakhir; dalam hal ini yang dimaksud dengan makhluk hidup mencakup manusia, hewan, dan/atau tumbuhan sedangkan yang dimaksud sebagai jasad renik adalah makhluk hidup yang berukuran sangat kecil dan tidak dapat dilihat secara kasat mata misalnya amuba, ragi, virus, dan bakteri. Sedangkan yang dimaksud dengan proses biologis yang esensial 
untuk memproduksi tanaman atau hewan adalah proses penyilangan yang bersifat konvensional dan/atau alami misalnya melalui teknik cangkok, stek dan lain sebagainya, sedangkan proses non-biologis atau proses mikrobiologis adalah proses produksi tanaman atau hewan yang biasanya bersifat transgenic/rekayasa genetika yang dilakukan dengan memanfaatkan proses kimiawi, fisika, penggunaan jasad renik, atau bentuk rekayasa genetika lainnya.

Sehubungan dengan itu, Indonesia menciptakan regulasi peraturan dengan harapan bahwa hak komunal bagi masyarakat yang bersinggungan langsung dengan hal demikian tidak terganggu dan tidak akan merasa dirugikan. Sebagai contohnya petani Indonesia memiliki perlindungan tentang komersialisasi suatu benih pangan yang memang hal tersebut merupakan suatu ketahanan nasional. Sehingga hak paten dalam hal ini tidak dapat dipaksakan karena dianggap akan mengganggu petani dalam mengembangkan hasil panennya, sehingga akan berakibat fatal apabila hal tersebut pada akhirnya akan dimonopoli oleh seseorang atau suatu badan hukum saja.

Sistem paten merupakan bagian yang terintegrasi tidak saja karena telah berlaku sebagai suatu hukum postif di negara tertentu, melainkan juga karena adanya perkembangan konsep dan doktrin mengenai hak paten yang diwujudkan dalam kesepakatan-kesepakatan atau perjanjian-perjanjian internasional baik yang membahas tentang kekayaan industri secara umum ataupun mengenai hak paten secara khusus. Sedikitnya ada 4 (empat) konvensi dan/atau perjanjian yang berkaitan dengan pengaturan hak paten, diantaranya adalah The Agreement on Trade Related Aspects of Intellectual Property, The Paris Convention for the Protection of Industrial Property, Paten Cooperation Treaty (PCT), dan Budapest Treaty on the Recognition the Deposit of Microorganisms for the Purposes of Patent Procedures. (Margono, 2011 : 130). Dari keempat perjanjian ini terdapat tata cara penggolongan invensi yang dapat dipatenkan serta tata cara penerimaan pendaftaran invensi oleh 
inventor, yang kemudian

diregulasikan kedalam hukum nasional setiap negara peserta dari perjanjian internasional tersebut.

Penelitian ini dikhususkan dalam The Agreement on Trade Related Aspects of Intellectual Property sebagai pedoman umum dalam perjanjian internasional dalam bidang hak kekayaan intelektual. Adapun regulasi dari TRIPs dalam perundang-undangan Indonesia khususnya dalam Undang Undang Paten terlihat di dalam beberapa pasal dalam TRIPs yang banyak diadopsi oleh pemerintah Indonesia diantaranya yakni: Article 1, Article 2, Article 3, Article 4, Article 27, Article 28, Article 29, Article 30, Article 31, Article 32, Article 33, Article 34, namun isu yang lebih khusus terdapat dalam ketentuan Article 1 point (1), Article 27, dan Article 30 yakni

Article 1 point (1) "Nature and

Scope of Obligations"

"Members shall give effect to the provisions of this Agreement. Members may, but shall not be obliged to, implement in their law more extensive protection than is required by this Agreement, provided that such protection does not contravene the provisions of this Agreement. Members shall be free to determine the appropriate method of implementing the provisions of this Agreement within their own legal system and practice."

Article 27"Patentable Subject Matter"

"1. Subject to the provisions of paragraphs 2 and 3 , patents shall be available for any inventions, whether products or processes, in all fields of technology, provided that they are new, involve an inventive step and are capable of industrial application. Subject to paragraph 4 of Article 65, paragraph 8 of Article 70 and paragraph 3 of this Article, patents shall be available and patent rights enjoyable without discrimination as to the place of invention, the field of technology and whether products are imported or locally produced.

2. Members may exclude from patentability inventions, the prevention within their territory of the commercial exploitation of which is necessary to protect ordre public or morality, including to protect human, animal or plant life or health or to avoid serious prejudice to the environment, provided that such exclusion is not made merely because the exploitation is prohibited by their law. 
3. Members may also exclude from patentability:

(a) diagnostic, therapeutic and surgical methods for the treatment of humans or animals; (b) plants and animals other than micro-organisms, and essentially biological processes for the production of plants or animals other than nonbiological and microbiological processes. However, Members shall provide for the protection of plant varieties either by patents or by an effective sui generis system or by any combination thereof. The provisions of this subparagraph shall be reviewed four years after the date of entry into force of the WTO Agreement".

Article 30 "Exceptions to Rights Conferred"

"Members may provide limited exceptions to the exclusive rights conferred by a patent, provided that such exceptions do not unreasonably conflict with a normal exploitation of the patent and do not unreasonably prejudice the legitimate interests of the patent owner, taking account of the legitimate interests of third parties."

Dalam ketentuan-ketentuan tersebut dapat disimpulkan bahwa. Pertama dalam Aricle 1 point (1) TRIPs, setiap anggota peserta TRIPs dapat melaksanakan ketentuan ketentuan dasar yang tercantum dalam TRIPs. Dalam hal ini setiap negara anggota diperbolehkan untuk mengadopsi ketentuan-ketentuan tersebut, namun anggota tidak diwajibkan untuk menerapkan ketentuan tersebut dalam hukum nasional mereka secara lebih luas di luar dari perjanjian TRIPs atau yang bertentangan dengan perjanjian tersebut. Selain itu, negara anggota diberikan kebebasan untuk menentukan metode yang tepat dan benar untuk melaksanakan perjanjian tersebut di dalam hukum nasional mereka (Prinsip National Treatment).

Yang kedua, dalam Aricle 27 point (1) joAricle 27 point (3) TRIPs adalah bahwa Invensi yang berupa teknologi harus memenuhi unsur kebaruan, mengandung langkah inventif, serta dapat diaplikasikan dalam perindustrian. Selain itu pemberian hak paten harus dibuka pada setiap negara anggota tanpa adanya diskriminasi karena adanya perbedaan tempat/lokasi penemuan, bidang teknologi atau terapannya, serta produk yang diimpor, atau diproduksi hanya di negara tersebut. 
Namun dari pada itu anggota dapat mengecualikan invensi paten, untuk pencegahan dari eksploitasi komersial yang diperlukan untuk melindungi moral atau ketertiban umum, termasuk untuk melindungi manusia, hewan atau tumbuhan hidup atau kesehatan di wilayah mereka atau untuk menghindari masalah yang serius terhadap lingkungan, pengecualian tersebut disediakan bukan hanya karena alasan eksploitasi yang dilarang oleh hukum mereka. Namun lebih ke arah kepentingan sosial dan budaya yang berguna untuk melangsungkan kesejahteraan hidup masyarakat di negara tersebut. Begitu pula pada Article 3 yang memberikan kewenangan kepada negara anggota untuk mengatur dan membuat sendiri hukum nasionalnya dibidang Paten.

\section{Implikasi Hak Paten dan Tanggung Jawab Pemerintah dalam Perkembangan Teknologi dan Importasi Bagi Indonesia.}

Adanya
teknologi tidak saja dapat
memajukan perekonomian suatu
negara, tetapi juga makin memajukan
teknologi itu sendiri melalui kegiatan

Research and Development (R\&D) dalam segala bidang. Masalah rekayasa genetika dan pengetahuan tradisional dalam suatu sisi, kemajuan IPTEK tidak dapat dibendung di sisi lain, bersinggungan dengan masalah moralitas dan agama (termasuk juga masalah social masyarakat komunal). Oleh karenanya, terdapat perbedaan antara negara yang mengagungkan kecanggihan IPTEK dengan masyarakat Komunal yang sedang berkembang sehingga dibuat regulasi perundang-undangan yang ketat dan negara-negara yang masih membatasi diri mereka berkenaan dengan rekayasa genetika tersebut (Purwaningsih, 2012 : 241).

Menurut Marzuki (2012 : 29) indigenous technological capabilities (kemam-puan memanfaatkan teknologi) adalah kemampuan untuk menyeleksi tekno-logi yang ditawarkan, kemampuan untuk menguasai teknologi yang diimpor, dan kemampuan untuk mengintroduksi hal-hal baru dalam proses menghasilkan produk-produk. Untuk meningkatkan penguasaan dan kemampuan bangsa di bidang 
teknologi diperlukan sarana perlindungan terhadap KI yang berupa Hak Paten. Dengan adanya perlindungan terhadap paten (dalam hal teknologi) akan sangat mendorong inovatif masyarakat Indonesia untuk menciptakan penemuan. Dari sudut pandang ini, perlu adanya perhatian khusus tentang aspek manfaat ataupun kerugian akibat adanya perlindungan paten, khususnya bagi pengembangan teknologi nasional.

Hakikat perlindungan paten adalah suatu hak eksklusif yang diberikan oleh negara sebagai penghargaan sekaligus imbalan atas suatu penemuan dengan dibatasi jangka perlindungan waktu tertentu dan dengan wilayah berlakunya sesuai dengan pendaftaran dan perlindungan tersebut. Pasal 1 ayat

(1) Undang Undang Paten menambahkan adanya pemberian hak paten kepada pihak lain untuk melaksanakannya. Untuk mencapai tujuan pengembangan teknologi, Undang Undang Paten telah menggariskan bahwa pemberian hak paten sejalan dengan ratifikasi Indonesia terhadap perjanjian- perjanjian internasional, perkembangan teknologi, industri, dan perdagangan yang semakin pesat, serta kepentingan masyarakat umum. Fungsi kontrol terhadap pelaksanaan Undang Undang Paten telah dilaksanakan oleh pemerintah dengan mengawasi pendaf-taran, penerimaan, dan transaksi hak paten dalam lalu lintas bisnis. Pasal 78 Undang Undang Paten menyatakan bahwa perjanjian lisensi tidak boleh memuat ketentuan yang secara langsung dan tidak langsung dapat merugikan perekonomian Indonesia dan juga perkembangan teknologi. Perlindungan paten diharapkan dapat menunjang kepentingan-kepentingan ekonomi dan teknologi, kaena paten pada dasarnya adalah perlindungan penemuan di bidang teknologi yang akan dimanfaatkan secara ekonomis dalam komersialisasi dalam dunia industri yang penuh persaingan.

Dalam prinsp-prinsip Undang Undang Paten utamanya disclosure clause yakni pengungkapan penemuan, terdapat dilemma bagi masyarakat dengan mempertimbangkan untung ruginya mendaftarkan paten, di samping 
faktor yang lain seperti biaya yang sangat mahal. Masyarakat yang enggan rahasianya terungkap karena dianggap akan mematikan bisnisnya akan memilih diam atau bahkan akan menempuh jalur permohonan pendaftaran Rahasia Dagang. Hal ini pantas saja terjadi karena adanya kebiasaan dalam berbisnis yang rahasia terhadap suatu teknologi harus dijaga hingga turun temurun, sedangkan yang jangka waktu perlindungan paten hanya 10 (sepuluh) tahun untuk paten produk dan 20 (dua puluh) tahun untuk paten proses.

Fakta bahwa pengetahuan dan keahlian suatu perusahaan yang tidak mudah ditiru oleh pesaingnya diperoleh dari suatu kegiatan R\&D yang memerlukan biaya yang sangat besar. Bila kemudian teknologi yang diperoleh ternyata tidak dilindungi oleh hukum, maka menjadi public domain. Kemerdekaan untuk memperoleh hak dari negara berkembang tidak serta merta membawa kemerdekaan ekonomi namun justru semua itu masih bergantung dari adanya keikutsertaan dari negara maju.
Perkembangan ekonomi menjadi suatu ketergantungan sosial terhadapnya, bila asal mula teknologi memang dibuat dan dikirim dari luar negeri serta dioperasikan di Indonesia sehingga impor peralatan menjadi besar. Pembelian peralatan teknologi dari luar negeri tentu akan dibayar dengan harga yang sangat mahal oleh Indonesia. Tentu hal ini karena faktor kebutuhan yang sangat mendesak bagi Indonesia, selain keahlian yang terbatas dari Indonesia, tidak mampu melakukan pengawasan dan alih teknologi terhadap produk dan proses industri yang dibuat. Oleh sebab itu, pengoptimalan teknologi tidak mampu dilaksanakan sebaik mungkin karena masih besarnya ketergantungan terhadap bantuan teknologi dari luar negeri. Alih teknologi menjadi suatu pilihan utama bagi Indonesia, dengan tujuan untuk memperoleh pengetahuan dan keahlian teknologi tersebut.

Menurut prinsip disclosure clause memang terbuka kesempatan untuk mendapatkan suatu informasi penting tentang teknologi dan paten, 
namun hal tersebut sangatlah kecil sekali mengingat setiap perusahaan asing akan mencoba sekeras mungkin untuk menyembunyikan informasi terkait pengungkapan teknologinya. Untuk itu Pemerintah Indonesia harus membuat suatu kebijakan yang memberdayakan instansi terkait peningkatan peran para ahli di bidang teknologi, melakukan kontrol terhadap perjanjian lisensi internasional dalam bidang alih teknologi maupun distribusi/ pemasaran produk, serta penegakan hukum yang tegas serta tidak hanya menjanjikan kepentingan ekonomi saja, namun juga lebih mementingkan kepentingan moral dan kepentingan nasional.

Perlu diingat bahwa TRIPs telah mencantumkan bahwa perlindungan hak paten, untuk kepentingan nasional suatu negara peserta, dimungkinkan untuk menyimpanginya. Dengan menjadi peserta dari TRIPs sekaligus emnghadapi perdagangan global yang akan terjadi, serta WTO yang menjadi pengawasnya, maka Indonesia harus berani membuat suatu kebijakan demi kepentingan nasionalnya untuk memajukan teknologi dan mengembangkan industri pasar nasional dan internasional. Kajian menemukan bahwa TRIPs selaku ketentuan dasar juga bersandarkan pada ketentuan Paris Convention, maka konvensi tersebut juga tidak semata-mata mendukung pengem-bangan dan ekonomi negara-negara berkembang dan terbelakang. Menurut Marzuki dalam Pasal 2 ayat (3) Paris Convention memungkinkan pengecua-lian namun bukan mengenai persamaan melainkan mengenai sistem prosedural dan yudisial.

Apabila kembali pada Paris Convention dan sejarah paten yang istem paten berkembang serta keberlanjutan alih teknologi, sebenarnya sistem paten pertama kali dituangkan dalam perundangundangan di Venesia tahun 1474 untuk melindungi serta mendorong penemuan dan teknologi baru. Menurut Marzuki terdapat suatu perbedaan mendasar antara sistem paten Eropa dengan sistem paten Amerika. Sifat sistem Eropa lebih proteksionis dibandingkan dengan 
Amerika dalam hal perlindungan terhadap adanya suatu penemuan.

Sistem paten memang memungkinkan suatu perusahaan asing menyalahgunakan posisinya karena memegang monopoli untuk memonopoli demi mendapatkan keuntungan yang sebanyakbanyaknya, sehingga dapat dikatakan hal tersebut bertentangan dengan inti dari filosofi perlindungan paten, yakni mendorong terjadinya penemuan, dalam asas perlakuan yang sama misalnya dalam Paris Convention Article 2 point (1), dalam hal pemohon paten, baik perusahaan internasional maupun perusahaan nasional harus diperlakukan secara sama dalam hukum. Ketentuan tersebut dirasa tidak adil karena kepentingan perusahaan internasional adalah mengkomersiali-sasikan invensinya dan memono-polinya sehingga akan menghambat pertumbuhan dan perkembangan kemajuan teknologi dari perusahaan nasional itu sendiri. Dari sisi tujuan kepentingan nasional seharusnya kebijakan nasional mengenai peningkatan ekonomi melalui perlindungan paten dapat mensiasati gempuran dari perjanjianperjanjian internasional terutama dalam TRIPs yang hanya merupakan norma standar. Memang dalam hal perlindungan suatu penemuan memiliki sisi individual dan sisi sosial yang kemudian diangkat menjadi kepentingan nasional untuk pertumbuhan ekonomi bangsa. Dari sisi individual adalah perlindungan terhadap hasil invensi yang telah berhasil ditemukan oleh seseorang atau kelompok, sedangkan dalam hal kepentingan nasional adalah menumbuhkan motivasi bagi inventor-inventor serta meningkatkan kesejahteraan masyarakat dengan cara menikmati hasil-hasil invensi tersebut.

Disamping terdapat manfaat, ada juga akibat negatif dari adanya perlindungan KI ini diantaranya adalah adanya hak monopoli sehingga menimbulkan biaya dan daya jual yang sangat tinggi, perusahaan yang memiliki sertifikat hak KI tidak mengeksploitasi hasil invensi mereka secara penuh kepada masyarakat

Sumantoro menyatakan walaupun sistem standarisasi 
perlindungan $\mathrm{KI}$ internasional dapat menjadi pendorong timbulnya penemuan, tetapi sistem tersebut dianggap tidak efektif dalam memberi kemudahaan terhadap alih teknologi terhadap negara berkembang. Hal tersebut terlihat oleh penemuan penemuan yang bahkan tidak bersifat perorangan untuk kepentingannya saja. Namun lebih bersifat kepada perusahaan yang akan dengan segan menganut konsep liberal dalam memonopoli, mengeksploitasi, dan mengkomersialisasi invensi mereka yang telah mendapatkan perlindungan paten. Dengan demikian Undang Undang Paten sebenarnya dapat menghambat alih teknologi bagi negara penerima karena hakikatnya negara penerima akan menjadi suatu pasar bebas dimana masyarakatnya akan lebih memiliki sifat konsumtif daripada sifat yang produktif.

Menurut Pasal 19 UndangUndang Paten, bahwa jika suatu produk diimpor ke Indonesia dan proses untuk membuat produk yang bersangkutan telah dilindungi Paten, Pemegang Paten Proses yang bersangkutan berhak atas dasar ketentuan Pasal 19 ayat (1) melakukan upaya hukum terhadap produk yang diimpor apabila produk tersebut telah dibuat di Indonesia dengan menggunakan proses yang dilindungi Paten.

Hal ini dapat diartikan bahwa Pemerintah hanya akan membatasi kegiatan Impor, apabila ada pengaduan mengenai penyalahgunaan terhadap suatu produk jadi yang ternyata proses untuk memproduksinya telah diberikan hak paten oleh inventor di Indonesia. Jadi pemerintah dalam hal ini tidak akan melakukan pembatasan terhadap impor dengan serta mertayang mana hal tersebut dapat dilakukan karena berhubungan langsung dengan kepentingan masyarakat. Hal ini ditentukan dengan tujuan agar terjadinya alih teknologi dapat dilaksanakan tanpa mengganggu kepentingan masyarakat dan juga tidak merugikan inventor Indonesia. 


\section{Simpulan}

Yang dapat diajukan permohonan pendaftaran suatu hak paten adalah invensi-invensi yang berkaitan dengan teknologi dan atau terapannya (termasuk Bioteknologi). Dalam sistem KI khusunya rezim paten melindungi suatu perwujudan atas produk yang memiliki fungsi dan nilai tertentu dalam kehidupan masyarakat umum. Dalam pengaturan pasar global ada beberapa perjanjian internasional yang dianggap menjadi landasan ketentuan bagi berjalannya sistem paten internasional. Adapun beberapa perjanjian international yang menjadi landasan ketentuan dalam hukum paten diantaranya adalah TRIPs Agreement, Paris Convention, PCT, Budapest Treaty, serta $C B D$. Ketentuan itu dibuat berdasarkan keperluan negara-negara maju untuk mempermudah pemasaran hasil invensi tidak hanya di negaranya saja namun juga di negara-negara lain di dunia. Akibatnya banyak negara khususnya Indonesia menjadi kalah saing dalam pemasaran di negaranya sendiri. Hal tersebut menjadi dampak dari adanya pengaturan dalam perjanjianperjanjian internasional tersebut, sehingga pengaturan terhadap paten nasional dianggap terlalu dipaksakan.

Dalam berbagai perjanjian internasional yang menjadi dasar terbentuknya suatu sistem hukum nasional mengatur tentang dasardasar dan tata cara mengenai regulasi hukum. Dalam regulasi perjanjian internasional yang menaungi sistem KI misalnya, setiap perjanjianperjanjian internasional tersebut memberikan kewenangan kepada setiap anggotanya untuk menentukan sendiri peraturan perundang-undangan mereka guna menaungi kesejahteraan dan daya guna masyarakat di negara tersebut. Dalam hal importasi misalnya, akan banyak sekali invensi-invensi asing yang masuk ke dalam daerah pabean Indonesia. Untuk itu pemerintah secara absolut dapat melakukan pembatasan dan pembatalan terhadap kegiatan impor. Hal tersebut sesuai dengan beberapa ketentuan yang dibuat dan diterapkan oleh masingmasing kementrian yang bersentuhan langsung dengan pemenuhan 
kebutuhan masyarakat Indonesia. Selain itu dalam perlindungan secara khusus yang ditentukan didalam Undang-Undang Paten, pemerintah dapat melakukan pembatasan hingga pembatalan impor atas dasar adanya upaya hukum yang dilakukan oleh inventor Indonesia.

\section{Daftar Pustaka}

\section{Buku}

Irawan, Candra. (2011)Politik Hukum Hak Kekayaan Intelektual Indonesia (Kritik Terhadap WTO/Trips Agreement Dan Upaya Membangun Hukum Kekayaan Intelektual Demi Kepentingan Nasional), Bandung: Mandar Maju

Margono, Suyud. (2011)Hak Milik Industri Pengaturan dan Praktik di Indonesia, Bogor: Ghalia Indonesia

Marzuki, Peter Mahmud. (2010)Penelitian Hukum. Jakarta: Kencana

Purba, Achmed Zen Umar. (2011) Perjanjian TRIPs dan Beberapa Isu Strategis, Jakarta: Penerbit Fakultas Hukum Universitas Indonesia bekerja sama dengan Penerbit P.T. Alumni

Purwaningsih, Endang. (2012) Hak Kekayaan Intelektual (HKI) dan Lisensi, Bandung : Mandar Maju

\section{Jurnal}

Direktorat Jenderal Perguruan Tinggi (DIKTI) Antibiotika dari Hewan Moluska, dikutip dari http://artikel.dikti.go.id/index. php/invensi/article/view/312 $<$ diakses tanggal 2 November 2015>

Marzuki Peter Mahmud, Luasnya Perlindungan Paten, Jurnal Hukum UII, No 12 Vol 6, Jakarta

\section{Peraturan Perundang-undangan}

The Agreement on Trade Related Aspects of Intellectual Property rights(TRIPs)

The Paris Convention for the Protection of Industrial Property

Undang Undang Nomor 14 Tahun 2001 tentang Paten

Undang Undang Nomor 18 Tahun 2002 tentang Penelitian, Pengembangan, dan Penerapan Ilmu Pengetahuan dan Teknologi

Peraturan Kepala BPOM Nomor HK.00.05.23.1455 tentang Pengawasan Pemasukan Pangan Olahan

Peraturan Kepala BPOM Nomor: HK.00.05.1.3460 tentang Pengawasan Pemasukan Bahan Baku Obat

Peraturan Kepala BPOM Nomor: HK.00.05.3.1950 
joHK.00.05.1.3459 tentang

Pengawasan Obat Impor

Peraturan Menteri Keuangan Nomor:

161/PMK.04/2007

tentang Pengawasan

Terhadap Impor dan Ekspor

Barang Larangan dan/atau

Pembatasan. 